\title{
ADOPTED FOREIGNERS INHERITANCE BY INDONESIAN CITIZEN
}

\author{
Muhammet Ebuzer Ersoy \\ International Turkish Reseacher of Istambul University Turkey \\ ebuzer ersoy@hotmail.com
}

\begin{abstract}
Adoption (pengangkatan anak) is governed by Law No. 23 of 2002 dated 22nd of Oct. 2002 concerning Child Protection; Decree of Minister of Social Affairs No. 44/HUK/1997 dated 31st of July 1997 concerning Fostering of Children Welfare through Adoption; Decree of Minister of Social Affairs No. 2/HUK/1995 dated 25th of Jan. 1995 concerning Completion of Attachment of Decree of Minister of Social Affairs No. 13/HUK/1993 concerning Implementation of Adoption; Supreme Court Circular Letter No. 2 of 1979 dated 7th of Apr. 1979 concerning Adoption; and Supreme Court Circular Letter No. 6 of 1983 dated 30 th of Sept. 1983 concerning Completion of Supreme Court Circular Letter No. 2 of 1979 concerning Adoption. Adoption is a legal act which distract a child from the environment of its parents, legal guardian, or other person responsible for the care, education and parenting, into a family environment with foster parents. It lawful both adoptions between Indonesian citizens and adoption among Indonesian citizens and foreigners. However, what legal consequences arising from the removal of the child? Is the adopted child could inherit from their foster parents or not? Or is there a way to pass down inheritance to adopted child who allowed the legislation? Therefore, this article will discuss.
\end{abstract}

Keywords: Adopted child; Erfstelling; Inheritance; Law; Wajibah Testament.

\section{A. INTRODUCTION}

Foster child is a child whose rights are transferred from a family of power environments parent or legal guardian, or other person is also responsible for the care, education, and raising the child, to the family environment adoptive parents by court decision or determination. Adoption is a legal act which distract a child from the environment of its parents, legal guardian, or other person responsible for the care, education and parenting, into a family environment with foster parents.

Adoption according to Article 7 of Government Regulation No. 54 of 2007 to separate the two types of adoption, namely:

\section{Adoption among Indonesian citizens ;}

2. Adoption among Indonesian citizens and foreigners.

Adoption (pengangkatan anak) is governed by Law No. 23 of 2002 dated 22nd of Oct. 2002 concerning Child Protection; Decree of Minister of Social Affairs No. 44/HUK/1997 dated 31st of July 1997 concerning Fostering of Children Welfare through Adoption; Decree of Minister of Social Affairs No. 2/HUK/1995 dated 25th of Jan. 1995 concerning Completion of Attachment of Decree of Minister of Social Affairs No. 13/HUK/1993 concerning Implementation of Adoption; Supreme Court Circular Letter No. 2 of 1979 
dated 7th of Apr. 1979 concerning Adoption; and Supreme Court Circular Letter No. 6 of 1983 dated 30th of Sept. 1983 concerning Completion of Supreme Court Circular Letter No. 2 of 1979 concerning Adoption.

Adoptions may only be implemented if in best interests of adoptive child. (Art. 39(1) of Law No. 23 of 2002 dated 22nd of Oct. 2002 concerning Child Protection). Adoptive parents must have same religion with adoptive child. (Id. at Art. 39(3)). Adoption by foreign citizens may only be conducted as last resort. (Id. at Art. 39(4)). Government and society provide guidance and supervision relating to adoption. (Id. at Art. 41(1)).

Three categories of adoptions are recognized in Indonesia: adoptions of Indonesian citizens by Indonesian citizens (Point 1(1) of Decree of Minister of Social Affairs No. 2/HUK/1995 dated 25th of Jan. 1995 amending Section II(3)(a) of Attachment of Decree of Minister of Social Affairs No. 13/HUK/1993 concerning Implementation of Adoption); (ii) adoptions of Indonesian citizens by non-Indonesian citizens (id. amending Section II.3(b)); and (iii) adoptions of foreign citizens by Indonesian citizens (id. amending Section II.3(c)). Adoptions must be approved by Minister of Social Affairs and registered with Department of Social Affairs. (Section IV(1) of Attachment of Decree of Minister of Social Affairs No. 13/HUK/1993).

Adoptive parents must: (i) have been married for at least five years unless doctor's letter certifying impossibility of having children is submitted with adoption application
(Point 1(2) of Decree of Minister of Social Affairs No. 2/HUK/1995 amending Section $V(A)(1)(a)$ of Attachment of Decree of Minister of Social Affairs No. 13/HUK/1993); (ii) be between ages of 30 and 45 years (Section $V(A)(1)(b)$ of Attachment of Decree of Minister of Social Affairs No. 13/HUK/1993); (iii) have no more than one child (id. at Section $\mathrm{V}(\mathrm{A})(1)(\mathrm{c})$ ); (iv) be of sound financial, physical and spiritual condition (id. at Section $V(A)(1)(d)$ and $(f))$; $(v)$ have good behaviour based on statement issued by Indonesian Police (id. at Section $V(A)(1)(e))$; (vi) provide written statement stating adoption is conducted for child's welfare (id. at Section $V(A)(1)(g)$ ); (vii) provide social report (laporan sosial) (id. at Section $V(A)(1)(h)$ ); (viii) have taken care of adoptive child for at least six months based on permit from Area Office Head of Department of Social Affairs (id. at Section VI(1)); and additionally, foreign adoptive parent applicants must: (a) obtain written agreement from state government of which they hold citizenship (id. at Section $V(A)(2)(b)$ ); and (b) have been working and living legally in Indonesia for at least two consecutive years supported by statement issued by authorized official (Point 1(3) of Decree of Minister of Social Affairs No. 2/HUK/1995 amending Section $V(A)(2)(c)$ of Attachment of Decree of Minister of Social Affairs No. 13/HUK/1993); (c) provide periodical report on child's development through Indonesian embassy in adoptive parent's respective country (Section $V(A)(2)(d)$ of Attachment of Decree of Minister of Social Affairs No. 13/HUK/1993). 
Foreign citizen children adopted by Indonesian adoptive parents and Indonesian citizen children adopted by foreign citizen parents may not be older than five years. (Point 1(4) of Decree of Minister of Social Affairs No. 2/HUK/1995 amending Section $\mathrm{V}(\mathrm{A})(3)(\mathrm{b})$ of Attachment of Decree of Minister of Social Affairs No. 13/HUK/1993). Foreign citizens may not adopt children who are already under parental care. (Section XI(1) of Attachment of Decree of Minister of Social Affairs No. 13/HUK/1993).

Examination of motives of adoptive parents and parents giving up child, including their sincerity, seriousness and awareness of consequences of adoption is substantial element of adoption process. (Point $\operatorname{IV}(3)(A)(3)$ (3.1) and (3.2) of Supreme Court Circular Letter No. 6 of 1983 dated 30th of Sept. 1983 concerning Completion of Supreme Court Circular Letter No. 2 of 1979 concerning Adoption).

Excerpted with permission from Sriro's Desk Reference of Indonesian Law.

\section{B. RESEARCH METHOD}

The research method is using Qualitative Research with the normative approach, that is take the sources of law such as International Child Adoption, International provisions, Any legal consequences appointment / adoption of the child, Islamic Law, Civil Law or BW, Customary law, Supreme Court, Terms Prospective Foster Parents and The Inheritance.

\section{RESULT AND DISCUSSION}

\section{International Adoption}

International adoption is already heavily regulated by numerous provisions in both the national and international regulations. Many benefits can be obtained if the legal actions to adopt a child internationally. Indonesian citizen adoption by foreign citizens can only be done as a last resort. This is in accordance with those listed in The Republic Government Regulation No. 54 of 2007 on the Implementation of Adoption. Many Things to watch on the procedures of adoption and what are the things that should be cared in implementing this legal act.

Adoptions aimed at the best interests of both children in child welfare and protection of children, based on local customs and the laws and invitation. There are some important things that must be considered if you want to hold this law, including:

a) Prospective adoptive parents must be of the same religion professed by candidates of the child.

b) Adoption does not decide a blood relationship with his biological parents.

c) Adoptive parents must inform about the origin of the child.

The terms of adoption according to PP No. 54 of 2007 are:

1) Not yet 18 years old

2) Child is being neglected

3) Being in family care or in a childcare institution

4) Require special protection 
If the above-mentioned regarding the Terms of kids who want to be adopted, it will be mentioned here are the terms of the prospective adoptive parents are:

a) Physically and mentally healthy;

b) Minimum age of 30 (thirty) years and a maximum of 55 (fifty-five) years;

c) The same religion as the religion prospective adopted child;

d) Good character and never convicted of a crime;

e) Married for a minimum of five (5) years;

f) Not a same-sex couples;

g) Not or have not had children or just have a child satuorang;

h) In a state capable of economically and socially;

i) Children's approval and written informed consent of parents atauwali child;

j) A written statement that the adoption is in the best interests of the child, child welfare and protection;

k) Their social reports from local social workers;

I) Has been nurturing prospective adoptive child of 6 (six) months, from parenting permission granted; and

m) Obtain a permit from the minister and / or the head of a social agency.

There are differences in procedures for child adoption between foreigners with an Indonesian citizen and vice versa. Indonesian citizen adoption by foreign citizen, should be qualified, as follows: a) Obtain written permission from the state government through embassy of applicant or applicant state representative in Indonesia

b) Obtain written permission from the minister, and

c) Through a childcare institution

Adoption of foreign citizens by Indonesian citizens should be qualified, as follows:

a) Obtain written approval from the government of the Republic of Indonesia

b) Obtain written consent from the child's home country government.

In addition to the requirements referred to above prospective adoptive parents are foreign citizens must also meet the following requirements:

a) Have resided in Indonesia valid for two (2) years

b) Written approval from the state government of the applicant; and

c) Make a written statement to report the child's development to the Ministry of Foreign Affairs of the Republic of Indonesia through the local The Republic Representative.

Request adoption Indonesian citizen by a foreign citizen who has qualified the above submitted to the Court to obtain a court ruling. In the process of adoption, the Minister is assisted by the Licensing Adoption Advisory Team.

\section{International Provisions}


In the Convention on the Rights of the Child are implemented the UN General Assembly on November 20, 1989 was also explained on the adoption of International Child universally valid for the countries which are bound therein. In this Convention once set about the rights of children and one including the provisions concerning adoption. Inside the convention universally described only about the regulations in the world, for the next convention asserts that the national regulations of a country should also apply to supplement the content of this convention. In one of the points in this Convention is explained also that the state should do all the things that can be done to implement the rights contained in the convention. Stated in article 9 that:

"The state must ensure that a child shall not be separated from her parents against their desire ..."

Not all countries in the world recognize their adoption, for a country which recognizes the adoption of legal act, it is only done in the best interests of the child, and then only a competent authority control and safety protection for children.

Article 21:

States Parties that recognize and / or permit the system of adoption shall ensure that the child's best interests must be taken into consideration they will: a) Ensure that the adoption of children is only authorized by the competent authorities determine that the adoption is permissible in view of the status of children associated with parents, relatives and legal guardianship and that, if needed, people who pay attention to the adoption on the basis of guidance that may be required, according law and applicable procedures and related and trustworthy. b) Recognize that inter-country adoption should be considered as an alternative means of child's care, if the child can not be placed in a foster family or adoption or can not be treated in the country of origin of children in any suitable manner. c) Ensure that children who have inter-country adoption enjoys safeguards and standards similar to those existing in the case of national adoption. d) Take all appropriate measures to ensure that, in inter-country adoption, the placement will not result in improper financial income for those involved in it. e) where appropriate, the objectives of the present article by concluding arrangements or agreements, bilateral or multilateral, within the framework, as well as efforts to ensure the placement of children in other countries carried out by the competent body or bodies. Placement will not result in improper financial income for those involved in it. e) where appropriate, the objectives of the present article by concluding arrangements or agreements, bilateral or multilateral, within the framework, as well as efforts to ensure the placement of children in other countries carried out by the competent body or bodies. Placement will not result in 
improper financial income for those involved in it. e) where appropriate, the objectives of the present article by concluding arrangements or agreements, bilateral or multilateral, within the framework, as well as efforts to ensure the placement of children in other countries carried out by the competent body or bodies.

For foreign child adoption of Act No. 62 of 1958 on citizenship of the Republic of Indonesia in chapter 2, it says:

a) Paragraph (1) Foreign Children 5 years old that have not been raised by a citizen of the Republic of Indonesia, Indonesia Repuplic acquire citizenship, if the appointment was declared invalid by the Court of residence of people who picked up the boy.

b) Paragraph (2) The statement referred thereto by the District Court must be requested by the person who lifted within one year after the Act comes into the legal draft. In the explanation sometimes adopted child said it was a foreign child, then granting citizenship of the Republic of Indonesia to the adopted son should be limited to young children. The purpose of foreign child adoption by a citizen of the Republic of Indonesia is mainly for the sake of the welfare of children.

\section{Any Legal Consequences Appointment / Adoption Child?}
a) Guardianship

In the case of a trust, since the decision is made by the court, then the guardian of the adopted child. Since then, all rights biological parents turn to the adoptive parents. Except for Muslim foster daughter, when she will get married then that could be the guardian of illegitimate only biological parents or siblings.

b) Inheritance

Both customary law, they are Islamic law and national law, has provisions regarding inheritance rights. All three have the same power, which means that one can choose the law which will be used to determine inheritance for adopted child.

\section{Islamic Law}

In Islamic law, adoption does not bring legal consequences in terms of blood relationship, the relationship of guardian and heir inheritance relationship with the adoptive parents. He continues to be the heir of the biological parents and the child kept the name of his biological father. In principle in Islamic law of inheritance is central to their relationship by blood or arhaam. However, the adopted child may inherit the street "Wajibah Testament" in accordance with the provisions of Article 209 Compilation of Islamic law that an adopted child entitled to $1 / 3$ (one third) of the Inheritance adoptive parents as a "Wajibah Testament".

\section{Civil Law or BW}


In 1917 Staatblaad No. 129, the legal effect of the adoption is the child legally obtain the names of the foster father, made as children born of the marriage of the adoptive parents and heirs of the adoptive parents. That is, due to the removal of the severed all civil relationships, which originate in the offspring since birth, which is between the biological parents and the child. Because the status of adopted child the same as biological children of foster parents it is thus the division of inheritance applies equally with biological children, as stated in Article 857 of the Civil Law/Code and applicable 'legitieme portie' article 913 to article 929.

\section{Customary Law}

When using traditional institutions, the determination of inheritance for adopted child dependent on customary law. For families who parental, adoption of Java instance is not automatically decide between the child's family ties with his biological parents. Therefore, in addition to getting the inheritance rights of adoptive parents, he also remains entitled to the inheritance of his biological parents. Unlike in Bali, adoption is a legal obligation to release the child from the family of origin to the foster family. The child becomes the biological child of the lifting and the forward position of his adoptive father. Adopting a foster child in Indonesia customary law should be bright, it means that must be done with a traditional ceremony and with the help of the head of customs.

\section{Supreme Court}

The Supreme Court did not close the eyes and ears against adoption. MA suggests there are judges who deviate from the provisions of the rules of adoption, especially by foreigners. In the past, the rule used is the Supreme Court Circular (SEMA) No. 2 In 1979, enhanced through SEMA No. 6 of 1983.

The issue of adoption by foreigners was raised again after the tsunami and earthquake in Aceh. To anticipate not to place false determination of the court, finally MA back to publish SEMA No. 3 Of 2005. One of the new things that set in SEMA 2005 PN obligation to report a copy of the determination of adoption in addition to the Human Right to the Supreme Court, Ministry of Social Affairs, Ministry of Foreign Affairs, Ministry of Health, the Attorney General and the Police.

The Supreme Court also gave three directives that must be considered before deciding determination judges adoption. Referral was also listed in the Act No. 23 of 2002 on Child Protection.

a) First, the adoption can only be done in the best interest of children. This is also the principle adopted by the Citizenship Law which was published in 2006.

b) Second, the prospective adoptive parents must coreligionists with the prospective adoptive child. When the child's origin is unknown, it is adapted to the majority of local occupation. According to $\mathrm{M}$. 
Joni, these rules prevent the adoption of a different religion. So the clash of authority between the PA and the PN is not going to happen.

c) Third, the adoption of children by foreigners can only be done as a last resort (U/timum Remedium). Even if the attempt was successful adoption, Article 40 of the Child Protection Law requires that the adoptive parents still tell the origins and biological parents to the child later.

Just as the adoption by the citizen, the citizen child adoption by foreigners is done through a court decision. However, there are additional requirements, namely:

a) obtain written permission from the applicant's home country governments through their embassies or representative of the applicant countries in Indonesia;

b) obtain written permission from the Minister; and

c) through childcare institutions.

In addition, the prospective adoptive parents should also be qualified foreigners:
a) have resided legally in Indonesia for two (2) years;
b) written approval from the state government of the applicant; and
c) make a written statement to the child's development report for the Ministry of Foreign Affairs of the Republic of Indonesia through the local Indonesian Representative.

Adoption or adoption is a legal act which distract a child from the environment of its parents, legal guardian, or other person responsible for the care, education and parenting, into a family environment with foster parents. ${ }^{1} \quad$ Basically adoptions consists of: ${ }^{2}$

a) adoptions between Indonesian Citizen

b) adoptions between Indonesian citizens with foreign citizens.

In the context of your question, we will explain the adoption in the second point above, the adoption of citizen to foreigners. This appointment is further subdivided into: ${ }^{3}$

a) adoptions by foreign citizen; and

b) foreigner in Indonesian adoption by citizen

Therefore, with respect to your question, let's talk about the adoption of children by foreign citizen. Actually adoptions by foreign citizen can only be done as a last resort. $^{4}$ So basically whenever possible adoption Indonesia was only done by the citizen as well.

Just as the adoption by the citizen, the citizen child adoption by foreigners is done through a court decision. ${ }^{5}$ While the terms

1 Article 1 point 2 of Government Regulation No. 54 Of 2007 on the Implementation of the Adoption "Regulation 54/2007"

2 Article 7 of Regulation No. 54 of 2007

3 Article 11, paragraph 1 PP No. 54 of 2007

4 Article 5 of Regulation No. 54 of 2007

5 Article 11, paragraph 2 of Regulation No. 54 of 2007 
and procedures adopted child adoption by foreigners through a court decision is basically the same with the appointment by the citizen. Learn more about the procedure and adoption can you see in the article Adopted, Procedures and disinherited, However, there are additional requirements adoptions by foreign citizen as in your question, which must meet the following requirements: 6

a) obtain written permission from the applicant's home country governments through their embassies or representative of the applicant countries in Indonesia;

b) obtain written permission from the Minister; and

c) through childcare institutions.

\section{Terms Prospective Foster Foreigner Parents}

Prospective adoptive

parents must meet the following requirements: ${ }^{7}$
a) physically and mentally healthy;
b) minimum age of 30 (thirty) years and a maximum of 55 (fifty-five) years;
c) the same religion as the religion prospective adopted child;
d) good character and never convicted of a crime;
e) married for a minimum of five (5) years;
f) not a same-sex couples;

6 Article 14 of Regulation No. 54 of 2007

7 Article 11 Regulation of the Minister of Social Affairs of the Republic of Indonesia No. 110 / Huk / 2009 on Adoption Requirements ( "Permensos No. 110 of 2009") g) not or have not had children or only have one child;

h) in a state capable of economically and socially;

i) children's approval and written informed consent of parents or guardians;

j) a written statement that the adoption is in the best interests of the child, child welfare and protection;

k) their social reports from local social workers;

I) has been nurturing prospective adoptive child of 6 (six) months, from parenting permission granted; and

m) obtain a permit from the Minister and / or the head of a social agency.

In addition to meeting the above requirements, the prospective adoptive parents should also be qualified foreigners ${ }^{8}$ :

a) have resided legally in Indonesia for two (2) years;

b) written approval from the state government of the applicant; and

c) make a written statement to the child's development report for the Ministry of Foreign Affairs of the Republic of Indonesia through the local Indonesian Representative.

\section{Inheritance}

Legacy issues, in the society we are often led to disputes which might lead to the outbreak of fraternal intimacy. In fact, It is unnecessary if we all understand 
what we should do, what are our rights, and what also become our duties relating to the inheritance. It less caused by ignorance and understanding, so much the culprit of the conflict. Indonesia's multicultural society with a plurality followed the civil law. Where Inheritance is one part of the Civil Code is growing very strong in Indonesian society. Because as we all know heirs inherit activities can not be separated from the system of people's lives. Heirs is one of the main elements in the Inheritance Law. In discussing Heirs, we must know what is meant by the Heir, the rights and obligations along with the classification well as possibilities concerning the status of beneficiary, to avoid misunderstandings followed up in daily life today.

a) Definition of Heirs

According to the Act/legislation, there are two ways to get an inheritance, namely: 1 .as heirs under the provisions of the Act/legislation. Since you were appointed in the will (testament). The first way is called inherited "by the Act/Law" or "ab intestato". While the second way is called the heir to "testamentair". In inheritance law applies the principle that when one dies, you instantly switch all the rights and obligations on all his heirs. This principle is stated in a French proverb that says: "/e mort saisit le vif", while the measurement of all rights and obligations of the deceased by heirs was called "saisine". Heir is any person who is entitled to inheritance heir and obliged to settle the debts. The rights and obligations arising after the testator dies. Inheritance rights was based on the marital relationship, blood ties, and testament, which is set in Law.

But legataris not heir, although he is entitled to inheritance heir, for his part is limited to the rights to certain objects without obligation. In Article 833, paragraph 1 Civil Law stated that all heirs by itself because of legal property rights over all the assets of the deceased (testator). In Article 874 Civil Law also stated that all the wealth of the deceased belonged to all the heirs according to law - legislation, just against it with the testament not taken a legal provision. The provisions of Article above is essentially based on the principle of "/e mort saisit le vif", which has been referred to above. Which means that people who die adhering to the people who are still alive.

This principle implies that every object must be an owner. Each heir entitled to demand and fight for the rights of kin, according to Article 834 BW An heir is entitled to demand any effort all the treasures that include the die assigned to him by his right as heir (heriditatis Petito). The prosecution rights prosecution of rights resembling an owner of an object, and according to the prosecution's intention 
should be addressed to the person who possesses an inheritance object with the intent to have it. Therefore, the prosecution should not be aimed at a just being houder, namely that the hang of it by a legal relationship with the deceased, such as rent. The prosecution can not be addressed to a executeur testamentair or a curator of an inheritance that is not taken care of. An heir who exercise their right to such prosecution, simply by filing a lawsuit in the letter, that he is the heir of the deceased to return the requested items included relics. According to Article 1066, paragraph 2 Civil Law each heir can demand the division of the estate even though there is no prohibition to do it. Thus, the estate may not be left in condition not be divided unless agreed not held shares, and even this is not longer than five years. Although the heirs of the right to inherit, which in principle everyone though a newborn baby is competent to inherit only by laws have been established there are people who because of his actions, inappropriate (onwaardig) received an inheritance. It is specified in Article 838 Civil Law deemed inappropriate so heirs, so it is excluded from the inheritance are:

1) those who have been convicted have been blamed for killing or trying to kill the testator;
2) those who are blamed for libel verdict has made heir that the testator has committed a crime punishable with a prison sentence of 5 (five) years or a more severe punishment;

3) those who with violence has prevented the heir to make or revoke a will;

4) those who have been obscure, destroy or falsify the will of the testator.

In addition, by law has established that there are people - those relating to the position or job, or relationship with the deceased, are not allowed to receive profit from a will that is done by the deceased. These people, including the notary who made the will, and the witness who attended the making of the testament, the pastor who served or doctor who treated the deceased during his final illness. Even granting the beneficiary in the will to people might be the intermediary of a person ("tussenbiede komende personen") can be canceled. As the intermediaries by laws considered children and wives of people who are not allowed to inherit and tastement it.

Furthermore, in Article 912 set out the reasons that according to Article 838 mentioned above, causes a person should not be the beneficiary. Applicable also as an obstacle to be able to accept the gift - giving in a testament, except in Article 912 does not 
mention people who have tried to kill the person who left a legacy. If the deceased turns her will still leave a legacy of the man who has done so, it was regarded as a "forgiveness" of that person.

b) Terms of Heirs

In Article 832 Civil Law stated that according to the law. The law is entitled to be the heir, the family of flesh, both legitimate and outside of mating, and the husband or wife who lived the longest. In that case, when a good run in families, as well as the longest living between husband and wife, there is no, then all the treasures of the deceased, belong to the state, which the authorities will pay off all debts, property prices heritage just sufficient for it. Then based on Article 874 Civil Law declared all treasures someone who died, are the property of all the heirs according to law, merely to it with a will has taken a legal provision. According to Article 836 Civil Law expressed by considering the provisions of Article 2 Civil Law, that can act as an inheritance, one must have been born at the time of inheritance falls. Civil Law which Article 2 states that a child in the womb of a woman, is considered as having been born, when the interests of the child which also, however if the death of a birth, it is assumed he had never been there. So according to the article is in the terms of heirs are as follows:
1) has the right to inheritance heir, arising due to:

2) blood relations (Article 832 BW)

3) because a will (Article 874 BW)

4) must already exist and are still there when the testator dies (Article 836 BW), with regard to the provisions of Article 2 BW 3. The heir not people who otherwise do not deserve an inheritance or who refuse inheritance

The article concerning the improper become heirs, namely Article 838 BW which has been mentioned above in the previous section. If we review the inheritance of the terms mentioned above, there will arise a question, what if it is between two people who are heir died in the same time? BW of the provisions of Article 831 may be known in case two or more of the same or mutually heir died in the same time or in the same time but can not be proven who died first then between the two are not mutually heir.

c) Rights and Obligations Rights and Obligations Heirs

In order to determine the rights and obligations of the heirs it is necessary to know the rights and obligations of the testator. Heir rights arise before the opening of the treasures in the sense that the heir before she died rightfully stated his will in a testament or 
a will. The content and the will can be:

1) Erfstelling, which is a designation of one or a few people become heirs to get most or all treasures. The person appointed is called testamentair erfgenaam (heirs according to a will or in Islam is called "Wajibah Testament").

2) Legaat, is granting the right to a person on the basis of a special tastement or probate. Giving it can be:

[1] (right) one or more specific objects;

[2] (right) all of the kinds of specific objects;

[3] vruchtgebruik rights of part / whole inheritance (Article 957 Civil Law).

Obligations of the testator is determined is its right Restrictions laws. He should heed their legitieme portie, that a certain portion of the treasures that can not be waived by the person who left a legacy. Rights heirs may be broken out as follows: Once open the inheritance, the heirs are entitled to determine the attitude:

1) Receive the full (zuivere aanvaarding), which can be either expressly or otherwise. With a firm that is if the reception is outlined in a document containing its acceptance as an heir.

2) Neither is silent, or openly, if the heirs of the acts of acceptance as heir and actions should reflect the act of acceptance of inheritance, (accept) is to take, sell or pay off debt heir.

3) Accept with reserve (right to exchange) voorrecht van boedel beschriyving or beneffeciare aanvaarding. It should be stated at the district court clerk of inheritance open place. As a result of the most important in inheritance in beneficare this is that the obligation to pay off debt and other expenses of the testator is limited such that repayment is limited by the power of inheritance, in this case mean that these heirs do not have to bear the debt repayment with the wealth itself, if debt heir is greater than possessions.

4) Recording their inheritance within four (4) months after he declared his will to the clerk of the district court, that he had received an inheritance in beneficiair.

5) Take care of inheritance as well - good.

6) As soon as affairs in inheritance ( "tot boedel effenheid brengen").

7) When asked by everyone indebted dependents must provide for the price of objects that move along with the objects that are not moving are not handed over to the people - those who hold hypothek indebted.

8) Provide an answer to all debt collectors and people who receive legaat 
administration. This job is in the form of calculating prices and revenues that may be obtained, if the goods sold inheritance and to what percentage of accounts receivables and legaten it can be met.

9) Calling someone - indebted people who are not wellknown, in the official gazette.

10)Rejecting inheritance. This is possible if you find that the amount of assets in the form of debt obligations greater than the right to enjoy the treasures. Rejection shall be carried out with a statement to the local district court clerk. Obligations of heirs, among others:

11)Maintain the integrity of legacy assets before inheritance is divided.

12)Looking for a way division in accordance with the provisions and others.

13)Pay off debt leaving the heir if the testator.

14)Will execute if any.

d) Classification of Heirs and Parts There are two kinds of heirs stipulated in the Act/legislation that is Heir by intermarriage and blood, and heirs by testament. Heirs who first called Heir ab intestato, while the second is called the beneficiary testamentair. Heirs ab intestato Civil Law regulated in article 832, declared that the right to be a beneficiary is the family of flesh and wife (husband) who still alive and if these do not exist, then it deserves to be the beneficiary is the State.

The question is who are the included in the family of flesh entitled to inherit it? To answer that we can see in BW, where the beneficiary can be divided into four (4) categories heirs, namely:

\section{Group I:}

This group consists of children and their descendants down without widows or widowers and their limits. According to the provisions of Article 852 Civil Law, children children born of the marriage despite different and different times, men or women get the same section, heir head for the sake of the head. Children who inherit in lieu of the father (mother) inherit the stake for the sake of the stake. Saplings are all children of a beneficiary who is entitled receive, but had died first. Then the neighbor's adopted son, Ali Afandi, SH stated that the parallel position adopted child as a child born in the marriage of adopting it. According to the provisions of Article 852 a Civil Law, part of a wife (husband) if there is a child of the deceased the same as part of a child who died. If marriage is not the first marriage and from marriage that previously there was also a son, then part of the wife (husband) it should not be more than the smallest part of the child heir. However a wife should not be more than a 
quarter of the estate. What is meant by the "least" is part of a child with the provisions of a will can be different, as long as not less than legitieme portie. Furthermore, in Article 852 b Civil Law, determined that if the wife (husband) heir together - with people - other people than in children or descendants of the first marriage, then he can withdraw all or part of the household in power. What is meant by "people of the child " it is people who become heirs as defined by wills. Household furniture price it will be deducted from the inheritance of the wife (husband) it. If it costs more bazaar than his share price then the price advantages that must be paid prior to the friend (or) the beneficiary.

\section{Group II:}

This group consists of the father and / or mother of the heir and his brother and his descendants until the degree to 6 (six). According to the provisions of Article 854 Civil Law, if one dies without leaving the offspring and the wife (husband), while the father and mother were still alive, then it is entitled to inherit is the father, mother and brother as follows:

1) Father and mother got a third of the inheritance, if the deceased had only one brother, which gets a third of rest, b.father and mother each got a quarter of the inheritance, if the deceased had more than a brother, which gets two and a quarter excess. Furthermore, in Article 855 Civil Law determined that if the person who died was without leaving descendants and wife (husband), while the father or mother is still alive, then:

2) Fathers or mothers receive half of the inheritance, if the deceased had only one brother, which gets half of rest; b. The father or mother gets one-third of the inheritance, if the deceased has two brothers which gets two-thirds of the excess; c. The father or mother gets one-quarter of the inheritance, if the deceased had more than two brothers, which gets threequarters of the excess. If the father and mother had died, then the whole estate became part relatives brother (Article 856 Civil Law). The division between brothers - sisters are the same, if they have a father and mother of the same. (But contrary the father or mother of the division only by division only between spouses) When they come from the marriage differently (the father of the same but the other mothers, or mothers alike but other father), then the inheritance is divided in two. The first section is for the line of father' $s$ parts and the second part is a 
part for the mother. Brothers - brothers who have the same father and mother got a part of the section of the line of father and mother. Brothers sisters who just can be father or the same mother from the father or maternal line only (Article 857). If the person who died left no offspring wife or husband, brother, father or mother while still alive. Then the father or mother who is still alive it inherits all the children who died world inheritance it (Article 859 Civil Law)

\section{Group III:}

This group consists of a family of flesh in a straight line upwards. According to the provisions of Article 853 and Article 858 Civil Law if the person who died left no offspring, as well as spouses, siblings, or parents, inheritance would fall to the grandparents. In this case the estate was split into two. One part was given to grandparents revealed the father and one piece again given to grandparents who lowers the mother. If the grandparents do not exist, then the inheritance falls to the parents of grandparents (greatgrandmother). If that is not the only grandparents, then the fall in his line, and become part of the living. Heir to the nearest degree in a straight line upwards, gets half the inheritance in line with his exclude all other heirs. All the family of flesh in a straight line upward in the same degree gets a part of head for the sake of the head (equal parts).

\section{Group IV:}

This group consists of a family of flesh in the line farther laterally to some degree to 6 (six). If the person who died left no offspring, spouses, siblings, parents, grandparents, then according to the provisions of Article 853 and Article 858, paragraph 2 Civil Law inheritance falls on the nearest Heir on each line. If there are some people who are the same rank, then the inheritance is divided based on the same section. Family incest in the line deviates by more than degrees to 6 (six) are not inherited. If the lines of the no family blood in degrees that allows to inherit, then all the blood relatives in the other lines obtain the entire inheritance (Article 861 Civil Law). If everyone who is entitled to inherit nothing else, then the whole legacy can be sued by the child outside the mating recognized. If the child is outside the mating even this did not exist, then the whole inheritance falls on the State (Article 873 paragraph 1 and Article 832 paragraph 2 Civil Law). With the enactment of laws - marriage Act No. 1 of 1974 the child inheritance beyond mating although admittedly, is no longer relevant. Act No. 1 of 1974 only recognized the legitimate children and children who outer 
mating (invalid). Legitimate child is Heir, while outside children marry only entitled to inherit from the mother who gave birth and by blood from the mother's side. Act No. 1 of 1974 only recognized the legitimate children and children who outer mating (invalid). Legitimate child is Heir, while outside children marry only entitled to inherit from the mother who gave birth and by blood from the mother's side. Act No. 1 of 1974 only recognized the legitimate children and children who outer mating (invalid). Legitimate child is Heir, while outside children marry only entitled to inherit from the mother who gave birth and by blood from the mother's side.

e) Heirs The Ineligibility heir According to the provisions of Article 838 Civil Law, deemed inappropriate became Heir and therefore not entitled to inherit are:

1) those who have been convicted have been blamed for killing or attempting to kill the heir.

2) those with the judge's ruling was blamed for the defamation complaint against the heir regarding a crime that is punishable by a prison sentence of 5 (five) years or more severe punishment.

3) those who with violence has prevented or revoked. those who have been obscure, destroy or falsify the terms testamentary heir. In contrast to Civil Law is customary inheritance laws.

a. Meanwhile, according to Islamic law, people who are not entitled to inherit are:

4) The heir killer, based on the hadith narrated by AtTirmidhi, Ibn-Majah, Abu Dawud, An-Nasai.

5) apostates are out of Islam, based on the hadith narrated by Abu Bardah.

6) The people of different faiths to the deceased, that is, those not embrace Islam or Gentile, based on the hadith narrated by Bukhari, Abu Dawud, Ibn Majah, AtTirmidhi.

7) The child of adultery, the thistles born of a relationship outside marriage, based on the hadith narrated by AtTirmidhi.

Not entitled to inherit are also heirs who refuse the inheritance in Article 1058 determined that an heir who refused legacy never be considered heirs. The rejection was retroactive until the time of death of the testator. According to Article 1059 Civil Law part of Heirs who reject it falls on the other heirs, as if the heir who refused it never existed. According to Article 1057 Civil Law denial of inheritance must be stated emphatically District Court Secretariat. According to Article 1062 Civil Law also 
stated that the right to refuse the inheritance can not fall because of the expiration. Rejection of the legacy it should be voluntarily on their own, if it happens on rejection of coercion or fraud, then refusal pursuant to Article 1065 Civil Law it can be canceled (eliminated). But voluntary rejection should not be done on the grounds do not want to pay the debt. If this occurs, pursuant to Article 1061 Civil Law judge may authorize the creditors of the heirs who reject it to be a substitute on his behalf to accept the inheritance.

f) Heirs Substitute

Civil Law distinguish
between heirs "uit eigen
hoofed" and heir "bij
plaasvervulling". Heirs "uit
eigen hoofed" are heirs who
inherit based on its position
itself against the heir, such as
children of the testator, wife /
husband heir. Heir "bij
plaasvervulling" is a substitute heirs entitled to inherit since people have died sooner than the heir. Suppose a father have to die earlier than the grandparents, the children's father who died that take the place of his father as heir of his grandfather.

This replacement occurs in the bottom line and the case indefinitely. Each heir who died first were replaced by their children. If more than one child as his successor, the reimbursement is calculated as a branch, meaning that all children who replaces it to get the same section. Replacement can also occur in families in the side line. Each brother heir to both siblings and half-brother, if died first, was replaced by his son. This replacement can also be without limit. Each replacement counted as one branch (bij staken). According to the provisions of Article 841 is the right replacement Civil Law give to someone to replace a deceased beneficiary more advance of the heir to act as a substitute in the degree and in the right of his predecessor. This reimbursement under section 842 Civil Law occurs only in a straight line down indefinitely, while Article 843 Civil Law in a straight line upwards there is no replacement. In case there is a replacement, then under section 846 Civil Law division performed stake for the sake of the stake.

\section{CLOSING}

In Islamic law, adoption does not bring legal consequences in terms of blood relationship, the relationship guardian and heir inheritance relationship with the adoptive parents. $\mathrm{He}$ continues to be the heir of the biological parents and the child kept the name of his biological father. In principle in Islamic law of inheritance is central to their relationship by blood or arhaam. However, the adopted child may inherit the street "Wajibah Testament" in accordance with the provisions of Article 209 Compilation of Islamic law that an adopted child 
entitled to $1 / 3$ (one third) of the Inheritance adoptive parents as a "Wajibah Testament". But if the heir to the use of western law to bequeath his entire estate to his adopted son a good citizen or foreigner for any reason, either because it has no other offspring on Erfstelling system. Erfstelling which is a designation of one or a few people become heirs to get most or all treasures. The person appointed is called testamentair erfgenaam (heirs according to a will or in Islam is called "Wajibah Testament" vruchtgebruik right based on partial / entire inheritance (Article 957 Civil Law) and because of the will (Article 874 BW).

\section{BIBLIOGRAPHY}

\section{Book:}

Brodzinsky D, editor. The Psychology of Adoption. Oxford; Oxford University Press; 1990

Brodzinsky DM, Schechter MD, Marantz Hening R. Being Adopted: The Lifelong Search for Self. New York: Doubleday; 1992

Civil Law/Code

Government Regulation No. 54 of 2007 on the Implementation of Child Adoption

Hansen, M. E. (2007). Using subsidies to promote the adoption of children from foster care. Journal of Family and Economic Issues, 28, 377-393. doi: $\quad 10.1007 / \mathrm{s} 10834-007-9067-6 . \quad$ Retrieved from http://www.ncbi.nlm.nih.gov/pmc/articles/PMC2646856/

Hartinger-Saunders, R. M., \& Trouteaud, A. R. (2015). Underserved adoptive families: Disparities in postadoption access to information, resources, and services. Journal of Family Strengths, 15(1), Article 6. Retrieved from

http://scholarworks.gsu.edu/cgi/viewcontent.cgi?article=1063\&co ntext=ssw_facpub

Home, A. (2015). Working with special needs adoptive parents: Insiders' perspectives on what professionals need to know. Professional Development: The International Journal of Continuing Social Work Education, 18(1), 49-55. Retrieved from

http://www.profdevjournal.org/articles/181049.pdf

Howard, J. A., \& Smith, S. L. (2003). After adoption: The needs of adopted youth. Washington, DC: Child Welfare League of America Press.

Howard, J. A., Smith, S. L., \& Ryan, S. D. (2004). A comparative study of child welfare adoptions with other types of adopted children and birth children. Adoption Quarterly, 7(3), 1-30. doi: 10.1300/J145v07n03_01 
Hudson, C., Cedeño-Zamor, P., Springer, C., Rosenthal, M., Silvia, S., Alexander, S., \& Kowal, L. (2006). The development of postadoption services in Massachusetts. In M. M. Dore (Ed.), The postadoption experience. Adoptive families' service needs and service outcomes (pp. 135-157). Washington, DC: Child Welfare League of America.

Melina L. Raising Adopted Children: Practical Reassuring Advice for Every Adoptive Parent. New York: HarperCollins Publishers Inc; 1998

Melina L. Making Sense of Adoption: A Parent's Guide. New York: HarperCollins; 1989

Melina L. Talking to children about their adoption: When to start, what to say, what to expect. Adopted Child. 2000;19:1-4

Maguire Pavao J. The Family of Adoption. Boston: Beacon Press; 1998.

Okun BF, Anderson CM. Understanding Diverse Families: What Practitioners Need to Know. New York: Guilford Press; 1996

Supreme Court Circular (SEMA) No. 2 In 1979, enhanced through SEMA No. 6 of 1983.

The Social Affairs Minister Regulation of the Republic of Indonesia No. 110 / Huk / 2009 of 2009 on Adoption Requirements

\section{Website:}

https://www.hukumonline.com/klinik/detail/ulasan/cl107/bagaimana-caramengadopsi-anak/ Accessed on November 5th, 2019.

https://nurassajatipurnamaalam.blogspot.com/2013/07/hukum-Inheritancesecara-perdata.html Accessed on November 5th, 2019.

https://irmadevita.com/2012/pembuatan-wasiat-oleh-orang-asing/ Accessed on November 5th, 2019.

https://etaholic.wordpress.com/2012/06/25/analisa-kasus-adopsi-anakinternasional-di-dalam-dan-di-luar-indonesia-berdasarkanketentuan-hukum-perdata-internasional-dan- Rail-rights-child-UN / Accessed on November 5th, 2019.

https://www.hukumonline.com/klinik/detail/ulasan/lt560d4c69baf81/aturandan-syarat-adopsi-anak-wni-oleh-wna/ Accessed on November 5th, 2019. 